\title{
Evaluation of phosphate sorption capacity and external phosphorus requirement of some agricultural soils of the southwestern Ethiopian highlands
}

\author{
Berhanu Dinssa ${ }^{1}$, Eyasu Elias ${ }^{2}$ \\ ${ }^{1}$ Departement of Plant Science, Ambo College of Agriculture, Ambo University, Ethiopia \\ ${ }^{2}$ Centre of Environmental Sciences, College of Natural Sciences, Addis Ababa University, Ethiopia
}

\section{ARTICLE INFO}

Keywords:

External $\mathrm{P}$ requirement

Freundlich equation

Phosphorous

P-sorption capacity

Article history

Submitted: 2021-05-20

Accepted: 2021-11-09

Available online: 2021-12-26

Published regularly: December 2021

* Corresponding Author

Email address:

berhanuddj@gmail.com

\section{ABSTRACT}

One of the most soil fertility management problems for crop production on acidic soils of the Ethiopian highlands is phosphorus fixation. The research was executed to assess the Psorption capacity and to determine the external $P$ requirement of different acidic soils in the Southwestern highlands of Ethiopia. Phosphorus sorption capacity (Kf) and its relation with selected soil characteristics were assessed for some major agricultural soils in the Ethiopian highlands to answer the questions, 'What are the amount of P-sorption capacity and external P requirement of Nitisols, Luvisols, Alisols, and Andosols in Ethiopia?'. Twelve surface soil samples (at depth of $0-30 \mathrm{~cm}$ ) were gathered and the P-sorption capacity was estimated. Phosphorus-sorption data were obtained by equilibrating $1 \mathrm{~g}$ of the 12 soil samples with $25 \mathrm{ml}$ of $\mathrm{KH}_{2} \mathrm{PO}_{4}$ in $0.01 \mathrm{M} \mathrm{CaCl}$, having $0,30,60,90,120,150,180,210$, 240, 270, 300, and $330 \mathrm{mg} \mathrm{P} \mathrm{L}^{-1}$ for 24 hours. The data were adjusted to the Freundlich adsorption model and the relationship among P-sorption and soil characteristics was established by correlation analysis. Clay content and exchangeable acidity, organic matter, $\mathrm{Al}_{2} \mathrm{O}_{3}$, and $\mathrm{Fe}_{2} \mathrm{O}_{3}$ oxides have affected phosphorus-sorption at a significance level of $(\mathrm{P}<$ $0.05)$. Alisols had the highest $\mathrm{Kf}$ value $\left(413 \mathrm{mg} \mathrm{kg}^{-1}\right)$ but Nitisols had the lowest $\mathrm{Kf}(280 \mathrm{mg}$ $\left.\mathrm{kg}^{-1}\right)$. The external phosphorus fertilizer requirement of the soils was in the order of 25, 30, 32, and $26 \mathrm{mg} \mathrm{P} \mathrm{kg}^{-1}$ for Nitisols, Luvisols, Alisols, and Andosols sequentially. The Kf varies among different soil types of the study area. The magnitude of the soil's Kf was affected by the $\mathrm{pH}$ of the soil, soil OM content, and oxides of Fe and Al. Therefore, knowledge of the soils' $P$ retention capacity is highly crucial to determine the correct rate of $P$ fertilizer for crop production.

How to Cite: Dinssa, B. \& Elias, E. (2021). Evaluation of phosphate sorption capacity and external phosphorus requirement of some agricultural soils of the southwestern Ethiopian highlands. Sains Tanah Journal of Soil Science and Agroclimatology, 18(2): 136-142. https://dx.doi.org/10.20961/stjssa.v18i2.51325

\section{INTRODUCTION}

Ethiopia has a diversity of topography, climate, vegetation, and parent materials, as a soil-forming factor, leading to the formation of various soil types (Elias, 2016). Nitisols and Luvisols are among the most extensive soil types covering about 31 and $11 \%$ of the arable landscapes of the Ethiopian highlands, whereas the highly productive Andosols are less extensively distributed (<1\%) (Elias et al., 2019). Alisols are particularly important in high rainfall upland farming systems of the Southwestern highlands of Ethiopia. Regardless of their area extent and agricultural importance, the phosphorus limitation of these soils has been constraining agricultural productivity in the Ethiopian highlands. Preliminary reports about the nutrient content of the Ethiopian soils suggest that $99 \%$ of the Ethiopian highland soils are phosphorus-deficient by taking $30 \mathrm{ppm}$ of available phosphorus as a critical level (Karltun et al., 2013). Studies on the nutrient status of the Ethiopian highland soils suggest that phosphorus deficiency is a major problem that negatively affects crop production (Elias et al., 2019; Melese et al., 2015).

A widespread problem of limited P-availability in soils might be due to severe P-fixation. Phosphate fixation is a process by which phosphate ions are retained on the active sites of the soil colloidal surfaces thus rendering it unavailable for plant uptake (Tamungang et al., 2014). Phosphorus fixation is a common problem in tropical rainfed upland farming systems (Hanyabui et al., 2020). The high P-retention by adsorption or precipitation reactions in soils results in low 
P-fertilizer use efficiency (15-30\%) (Maluf et al., 2018). The estimated $80 \%$ of the applied phosphate is not available for crop uptake as the result of high phosphorus fixation in acid tropical soils (Kisinyo et al., 2015). Most inherent characteristics of the soil that affect the degree of P-fixation include soil clay content, soil reaction $(\mathrm{pH}), \mathrm{OM}$ content, hydrated oxides of $\mathrm{Fe}$ and $\mathrm{Al}$, and the concentration of exchangeable aluminum and hydrogen (exch. $\mathrm{Al}^{3+}$ and $\mathrm{H}^{+}$) that varies with soil type (Wang et al., 2017). Likewise, Jiang et al. (2015) stated that the oxides of Fe and Al are the major adsorbents for phosphate ions in acidic tropical soils. When the clay fraction is composed of $1: 1$ minerals, iron, and aluminum oxides and hydroxides, most of the $P$ is adsorbed on the soil colloidal surfaces. The phosphorus sorption capacity $\left(\mathrm{K}_{\mathrm{f}}\right)$ of a soil refers to the potential of the soil to bind phosphorus applied to it and is a principal factor regulating $\mathrm{P}$ concentration in the soil solution and available phosphorus (Gonzalez-Rodriguez \& Fernandez-Marcos, 2018). The external $P$ requirement (EPR), also described as the standard $P$ requirement (SPR), is the amount of $P$ which must be applied to the soil to sustain a $\mathrm{P}$ level in the soil at $0.2 \mathrm{mg} \mathrm{P} \mathrm{L-}$ ${ }^{1}$ that meets the requirements in $\mathrm{P}$ for different crops (Wolde \& Haile, 2015).

Determination of the $K_{f}$ and EPR $f$ of various types of soils supports sustainable agriculture through site-specific $P$ fertilizer recommendations that avoid overdose $P$ application that led to adverse impacts on the economy and the environment. Underdoes application of $\mathrm{P}$ negatively impacts the growth potential of the crops and affects the living standard of the society through food self-insufficiency. Similarly, Thuy et al. (2020) stated that optimizing P fertilizer input could maximize the $P$ fertilizers use efficiency that will decrease fertilizer costs, improve income, and lower the negative impacts on the soil for sustainable agriculture.

Different mathematical models and sorption isotherms have been formulated to explore the soils $\mathrm{P}$ sorption capacity $\left(K_{f}\right)$; P-sorption energy $(1 / n)$, buffering capacity of soil versus $P$ concentration gradient in solution, and the state of equilibrium between $P$ in solution and the solid phases and their relation (Muindi et al., 2015). Freundlich model is the most commonly applicable model to determine P-sorption characteristics of soils and estimate EPRf (Afsar et al., 2012). This model can differentiate soils according to their capacity to absorb $P$ from soil solutions. Although studies have indicated the widespread P-sorption problem in Ethiopian soils (Wolde \& Haile, 2015). Information on P-sorption disaggregated by soil type is rather limited in the Southwestern highlands of Ethiopia. In recent years, Ethiopia is in the process of transforming its soil fertility sector by moving away from blanket fertilizer recommendation to soilspecific management of fertilizer (Elias et al., 2019). To this effect, to alleviate the P-sorption problem through soilspecific management (e.g., liming and targeted Pfertilization), it is necessary to estimate the degree of $\mathrm{P}$ fixation by dominant soil types. Hence, this research intended to evaluate the P-sorption capacity and external $P$ requirement of some acidic soils (Nitisols, Luvisols, Alisols, and Andosols) in the Southwestern highlands of Ethiopia.

\section{MATERIAL AND METHODS}

\subsection{Description of study sites}

The experiment was carried out on four dominant agricultural soils based on FAO classification (Nitisols, Luvisols, Alisols, and Andosols) in the intervention sites of the project; Capacity building for scaling up of evidence-based best practices in agricultural production in Ethiopia (CASCAPE) intervention woredas of Oromiya region, (Fig.1). The district is designated by flat plains, high mountains, and hilly topography, geological feature of the area is characterized by tertiary sediments of the Cenozoic era on the plain and basalt and volcanic rocks in the High Mountain and hilly ridges. The rainfall data obtained from the nearest weather stations (Bako and Jimma Agricultural Research Centers) reveals that the rainy season covers April to November and maximum rain is received in June, July, and August. The long-term (2009- 2018) mean annual rainfall is $1267-1730 \mathrm{~mm}$. It has a warm humid climate with average air temperatures of 19 to $21{ }^{\circ} \mathrm{C}$ and the altitudinal range of the sites is 1650 to $2800 \mathrm{~m}$ asl.

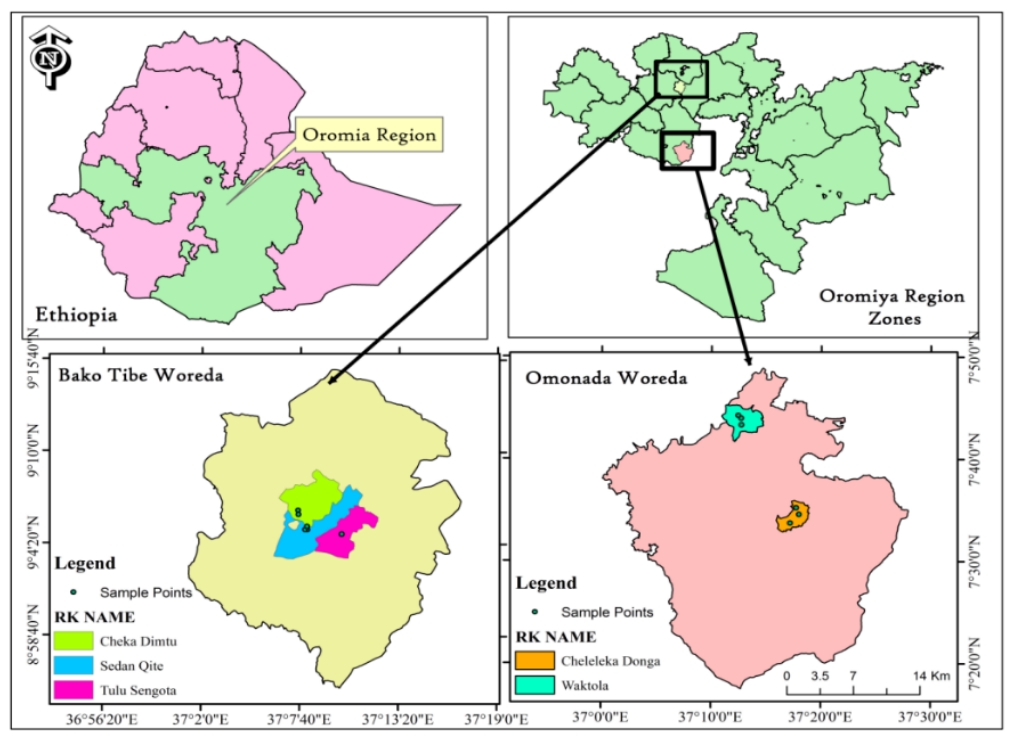

Figure 1. Location map of the study area 


\subsection{Soil sampling and laboratory procedures}

About ten representative sub-samples were taken from 0$30 \mathrm{~cm}$ depth randomly in a zig-zag manner from different spots of the sampling unit and one composite sample was formed ( $1 \mathrm{~kg}$ each). The sub-samples were thoroughly mixed together on a flat plastic sheet and 12 composite soil samples (3 samples from every type of soil) were collected in clean new plastic bags and transported to HortiCoops soil fertility laboratory. In the laboratory, the samples were dried on the air, crushed, sieved, and passed through a $2 \mathrm{~mm}$ mesh, to determine the soil physicochemical properties and $\mathrm{P}$ sorption capacity.

The soil particle size distribution was determined by the hydrometer method (Beretta et al., 2014). Soil $\mathrm{pH}\left(\mathrm{H}_{2} \mathrm{O}\right)$ was measured by a pH meter as described by (FAO, 2021). OM (\%) was determined by the wet digestion method (FAO, 2020). Exch. $\mathrm{Al}^{3+}$ and $\mathrm{H}\left(\mathrm{cmol}_{(+)} \mathrm{kg}^{-1}\right)$ were described by leaching with $\mathrm{KCl}$ followed by titration (Lestari et al., 2016). Determination of $\mathrm{Fe}_{2} \mathrm{O}_{3}$ and $\mathrm{Al}_{2} \mathrm{O}_{3}$ was following the $\mathrm{X}$-ray fluorescence (XRF) spectrometer (Towett et al., 2013).

Phosphorus sorption characteristics of the soil were analyzed by using three replicates of $1.0 \mathrm{~g}$, dry soil samples that weighed into $50 \mathrm{ml}$ centrifuge tubes and suspended in 25 $\mathrm{ml}$ of $0.01 \mathrm{M} \mathrm{CaCl}_{2}$ as supporting electrolytes that have 0,30 , $60,90,120,150,180,210,240,270,300$ and $330 \mathrm{mg} \mathrm{P} \mathrm{L}^{-1}$ as $\mathrm{KH}_{2} \mathrm{PO}_{4}$ with increasing rate of $30 \mathrm{mg} \mathrm{P} \mathrm{L}^{-1}$. Three drops of toluene were applied to all containers to stop the microbial action. The tubes were then closed and shaken on an end-toend shaker for 24 hours at a temperature of $25 \pm 1{ }^{\circ} \mathrm{C}$ at 150 oscillations per minute. After equilibrium, the soil suspensions were centrifuged at about $3000 \mathrm{rpm}$ for 10 minutes, then filtered through Whatman No. 42 to obtain a clear solution. The phosphorus in the supernatant was then analyzed following the Olsen procedure. The quantity of $P$ absorbed was calculated as the difference between the amount of $\mathrm{P}$ added and that of left in solution by Equation 1.

$\mathrm{P}_{\text {absorbed }}=\frac{(\text { Co-Cf }) \mathrm{V}}{\text { Weight ofsoil (kg) }}$

Where: $\mathrm{Co}=$ initial concentration of $\mathrm{P}\left(\mathrm{mg} \mathrm{L}^{-1}\right), \mathrm{Cf}=$ final concentration of $P\left(\mathrm{mg} \mathrm{L}^{-1}\right)$ and $V=$ volume of solution $(L)$. The soil $P$ sorption data were adjusted to the linearized forms of Freundlich (Equation 2).

$\mathrm{X}=\mathrm{KC}^{1 / \mathrm{n}}$
The logarithm of Eq. [2], changes into $\log X=\log k_{f}+1 / n$ $\log C$, the linear equation form 2 has been formulated by plotting $\log C$ against $\log X, X\left(\mathrm{mg} \mathrm{kg}^{-1}\right)=$ the concentration of $P$ retained per unit mass of soil, $C\left(\mathrm{mg} \mathrm{L}^{-1}\right)=$ the equilibrium concentration of $P, 1 / n\left(\mathrm{~L} \mathrm{~kg}^{-1}\right)$ represents the slope (the sorption energy) and $\log \mathrm{K}_{\mathrm{f}}\left(\mathrm{mg} \mathrm{kg}^{-1}\right)$ represents the sorption capacity in $\mathrm{mg} \mathrm{kg}^{-1}$ (Dari et al., 2015). The external phosphorus requirement $\left(E P R_{f}\right)$ is calculated based on Freundlich models by using the required $\mathrm{P}$ quantity $\left(0.2 \mathrm{mg} \mathrm{P} \mathrm{L}^{-1}\right)$ in the linear form of Freundlich equations (Getie et al., 2021). The Pbuffering capacity $(\mathrm{PBC})$ of a soil is its capacity to resist change in the $\mathrm{P}$ concentration of the solution phase (Shirvani et al., 2005). It was computed from the Freundlich adsorption isotherms at $0.2 \mathrm{mg} \mathrm{L}^{-1}$ of solution P as PBC (Eq. 3).

$\mathrm{PBC}=\mathrm{K}_{\mathrm{f}} * \mathrm{n} * \mathrm{C}^{\mathrm{n}-1}$

Whereas: PBC $\left(\mathrm{L} \mathrm{kg}^{-1}\right)=$ Phosphorus buffering Capacity; $\mathrm{K}_{\mathrm{f}}(\mathrm{mg}$

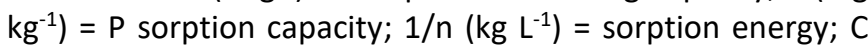
$\left(\mathrm{mg} \mathrm{L}^{-1}\right)=$ the equilibrium concentration of $\mathrm{P}$. The citrate bicarbonate dithionite ( $C B D$ ) procedure was used for the determination of total free iron oxides in soils (Fan et al., 2016).

\subsection{Statistical analysis}

The measured soil parameters were arranged in a Completely Randomized Design (CRD) with three replicates and subjected to analysis of variance (ANOVA) using the Statistical Analysis System (SAS) software version 9.4 (SAS Institute Inc, 2019). The Least Significance Difference test (LSD) at the $5 \%$ probability level was used for the mean comparison when the ANOVA showed significant differences. Also, a simple regression and correlation coefficient analysis was executed to assess the degrees and directions of the relationship between $\mathrm{K}_{\mathrm{f}}$ and the various soil parameters.

\section{RESULTS}

\subsection{Phosphorus sorption capacity of soils}

Table 1 shows highly significant $(P<0.01)$ variation among soils types for $\mathrm{P}$-sorption capacity $\left(\mathrm{K}_{\mathrm{f}}\right)$, level of $\mathrm{P}$-sorption energy $(1 / n)(P<0.05)$, and phosphorus buffering capacity $\left(\mathrm{PBC}_{\mathrm{f}}\right)(\mathrm{P}<0.01)$ but no significant difference in the external phosphorus requirement (Table 1 ).

Table 1. P-sorption capacity $\left(K_{f}\right)$, Slope $(n), E P R_{f}$ and $P B C_{f}$ values after 24 hours of equilibration

\begin{tabular}{|c|c|c|c|c|c|}
\hline $\begin{array}{l}\text { Soil Type } \\
\text { (RSG) }\end{array}$ & $\begin{array}{c}\mathrm{K}_{\mathrm{f}} \\
\left(\mathrm{mg} \mathrm{kg}^{-1}\right)\end{array}$ & $\begin{array}{c}1 / \mathrm{n} \\
\left(\mathrm{L} \mathrm{kg}^{-1}\right)\end{array}$ & $\begin{array}{c}\mathrm{EPRf}_{\mathrm{f}} \\
\left(\mathrm{mg} \mathrm{kg}^{-1}\right)\end{array}$ & $\begin{array}{c}\mathrm{PBC}_{\mathrm{f}} \\
\left(\mathrm{L} \mathrm{kg}^{-1}\right)\end{array}$ & $\mathrm{R}^{2}$ \\
\hline Nitisols & $280^{b}$ & $1.40^{\mathrm{b}}$ & 25 & $316^{b}$ & $0.95^{b}$ \\
\hline Luvisols & $336^{\mathrm{ab}}$ & $1.48^{\mathrm{ab}}$ & 30 & $395^{a b}$ & $0.97^{a}$ \\
\hline Alisols & $413^{a}$ & $1.67^{a}$ & 32 & $471^{\mathrm{a}}$ & $0.98^{a}$ \\
\hline Andosols & $299^{b}$ & $1.43^{b}$ & 26 & $346^{b}$ & $0.96^{\mathrm{ab}}$ \\
\hline Mean & 332 & 1.49 & 28 & 382 & 0.97 \\
\hline LSD\% & 0.15 & 66.07 & 37.41 & 80.27 & 0.003 \\
\hline SE & 32.79 & 0.08 & 5.0 & 37.76 & 0.007 \\
\hline $\mathrm{F}$ & 9.70 & 7.46 & 1.52 & 9.70 & 7.59 \\
\hline$P$ & 0.01 & 0.02 & 0.30 & 0.01 & 0.018 \\
\hline
\end{tabular}

Note: In the same column, means indicated by different letters are significantly varied at $\mathrm{p}<0.05 ; \mathrm{Kf}=\mathrm{P}$ sorption capacity; $1 / n=$ sorption energy; $\mathrm{EPR}_{\mathrm{f}}=$ Freundlich External $\mathrm{P}$ Requirement; $\mathrm{PBC} f=\mathrm{P}$ buffering capacity; $\mathrm{RSG}=$ Reference soil group. 


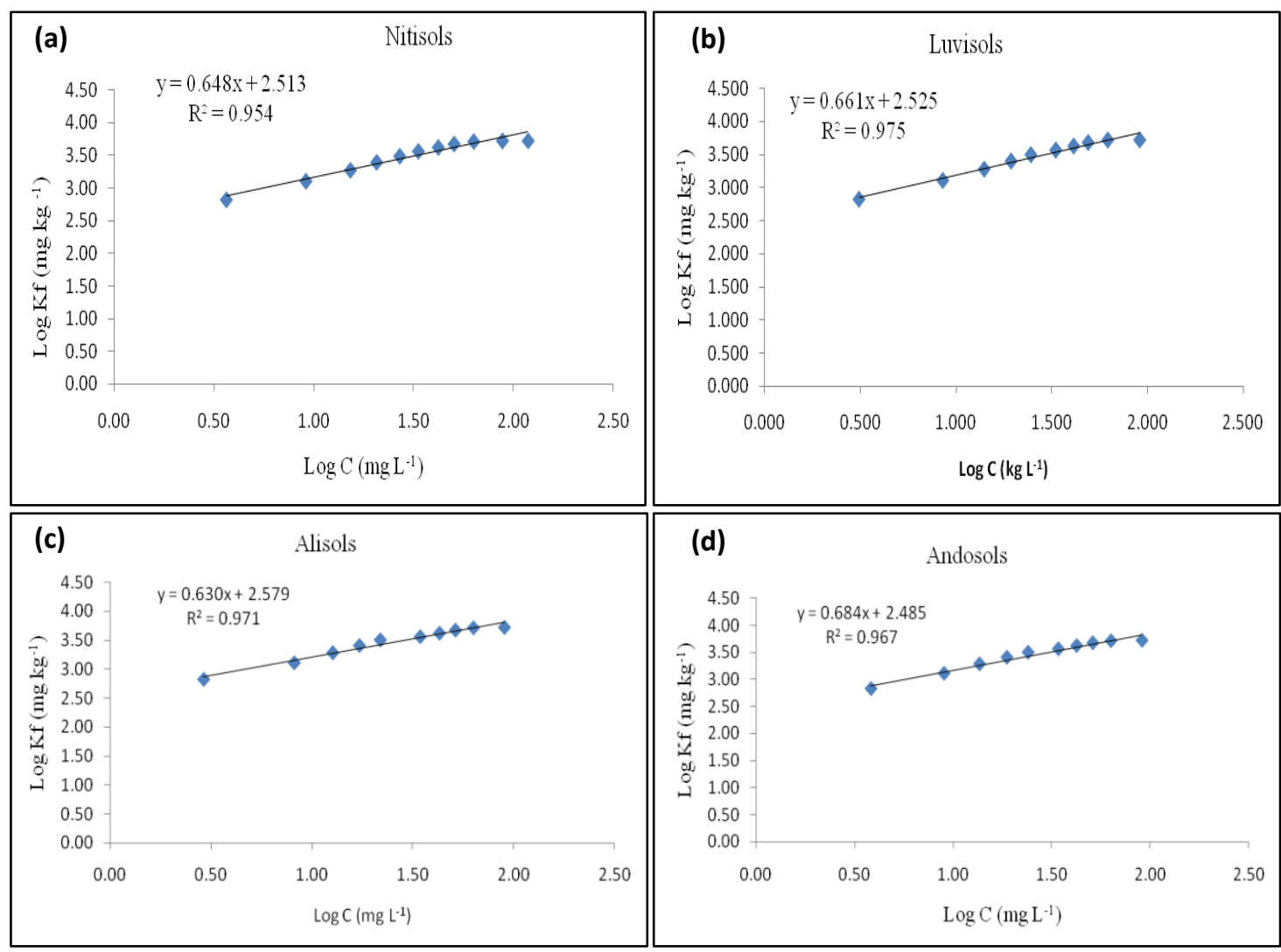

Figure 2. P sorption Isotherm for Nitisols (a), Luvisols (b), Alisols (c) and Andosols (d)

The sequence of soils based on their $\mathrm{K}_{\mathrm{f}}$ was Alisols > Luvisols $>$ Andosols $>$ Nitisols. Alisols had the highest $\mathrm{K}_{\mathrm{f}}\left(413 \mathrm{mg} \mathrm{kg}^{-1}\right)$ and $1 / \mathrm{n}\left(1.67 \mathrm{~kg} \mathrm{~L}^{-1}\right)$ but Nitisols had the lowest $\mathrm{K}_{\mathrm{f}}\left(280 \mathrm{mg} \mathrm{kg}^{-1}\right)$ and $1 / \mathrm{n}\left(1.40 \mathrm{~kg} \mathrm{~L}^{-1}\right)$. The linear form of the Freundlich equation formed by taking $\log C$ versus $\log X$ is displayed in Figure 2. It confirmed a satisfactory agreement with the Freundlich equation $\left(R^{2}=0.96-0.98\right)$ for the studied soils. The $\mathrm{P}$ sorption isotherms were formed by plotting the amount of $P$ adsorbed on the soil surface (Nitisols, Luvisols, Alisols, and Andosols) against the solution $\mathrm{P}$ concentration.

\subsection{The Soil External Phosphorus Requirement $\left(E P R_{f}\right)$ and Phosphorus Buffering Capacity (PBC)}

The actual quantities of $P$ required by Nitisols, Luvisols, Alisols, and Andosols were 25, 30, 32, and $26\left(\mathrm{mg} \mathrm{kg}^{-1}\right)$ respectively for optimum crop production at the study area (Table 1). The highest $\left(32 \mathrm{mg} \mathrm{kg}^{-1}\right)$ and the least $\left(25 \mathrm{mg} \mathrm{kg}^{-1}\right)$ values of $E R_{f}$ were obtained for Alisols and Nitisols respectively. The buffering capacity of soils was computed from the Freundlich adsorption isotherms at $0.2 \mathrm{mg} \mathrm{P} \mathrm{L}^{-1}$ of solution in the 24 hours of equilibration were $316,396,471$, and 346 for Nitisols, Luvisols, Alisols, and Andosols respectively (Table 1 ).

Table 2 shows there is variation in soil characteristics and $K_{f}$ among the soils. Accordingly, the mean clay content was significantly varied $(p<0.05)$ among various soil types, and the highest value (54.67\%) was observed under Alisols while the lowest value (36.0) was under Andosols. Even though statistically no significant difference in $\mathrm{pH}$ between the soils, Andosols had the highest (6.30) and Alisols had the lowest (4.80) $\mathrm{pH}$. There was a strong and significant $(p<0.001)$ difference in mean OM content between the soils. The highest value $(7.51 \%)$ and the lowest value $(3.36 \%)$ of OM were observed under Andosols and Alisols respectively. Significant ( $p$ $<0.05$ ) differences were observed in exchangeable aluminum (exch. $\mathrm{Al}^{3+}$ ) and exchangeable acidity (exch. Ac) of the soils under this study. Alisols had the highest exch. $\mathrm{Al}^{3+}(1.18$ $\left.\mathrm{cmol}_{(+)} \mathrm{kg}^{-1}\right)$ and exch. Ac $\left(1.67 \mathrm{cmol}_{(+)} \mathrm{kg}^{-1}\right)$ but Nitisols had the lowest (nill) exch. $\mathrm{Al}^{3+}$ and exch. Ac $\left(0.52 \mathrm{cmol}_{(+)} \mathrm{kg}^{-1}\right)$. The soils were strongly and significantly $(\mathrm{p}<0.001)$ differs in both $\mathrm{Al}_{2} \mathrm{O}_{3}$ (\%) and $\mathrm{Fe}_{2} \mathrm{O}_{3}(\%)$ content. Nitisols had the highest mean $\mathrm{Al}_{2} \mathrm{O}_{3}$ (26.68\%) and $\mathrm{Fe}_{2} \mathrm{O}_{3}(16 \%)$ while Andosols had the lowest mean $\mathrm{Al}_{2} \mathrm{O}_{3}(14.05 \%)$ and $\mathrm{Fe}_{2} \mathrm{O}_{3}$ (9.24\%). A significant $(\mathrm{p}<0.05)$ variation was observed among the soils in $\mathrm{K}_{\mathrm{f}}\left(413 \mathrm{mg} \mathrm{kg}^{-1}\right)$. Accordingly, Alisols had the highest and Nitisols had the lowest $\mathrm{K}_{\mathrm{f}}\left(280 \mathrm{mg} \mathrm{kg}^{-1}\right)$ values.

\subsection{Correlation between soil properties and P-sorption capacity}

The relationship between the $K_{f}$ and selected soil parameter is displayed in Table 3. Statistically, a positive and significant $(P \leq 0.05)$ relationship existed between exch. $\mathrm{Al}^{3+}$ and $K_{f}$. The $K_{f}$ had a positive and non-significant $(P>0.05)$ relationship with clay content, exch. $\mathrm{H}^{+}$, exch. Ac and aluminum oxides $\left(\mathrm{Al}_{2} \mathrm{O}_{3}\right)$ and iron oxides $\left(\mathrm{Fe}_{2} \mathrm{O}_{3}\right)$. In addition, the $\mathrm{K}_{\mathrm{f}}$ value had negative, non-significant $(\mathrm{p}>0.05)$ relationships with $\mathrm{pH}$ $\left(\mathrm{H}_{2} \mathrm{O}\right)$ and $\mathrm{OM}$ content of the soil. The sorption energy $(1 / n)$ had a positive non-significant $(P>0.05)$ relation with clay content while it had strongly significant positive relationships with exch. $\mathrm{Al}^{+3}$ at $(\mathrm{P}<0.001)$ level of significance and for $\mathrm{P}$ sorption capacity $\left(\mathrm{K}_{\mathrm{f}}\right)$ at $5 \%$ level of significance. Moreover, the equilibrium concentration of phosphorus, the slope (sorption energy) had non-significant $(\mathrm{P}>0.05$ ) relationships with soil $\mathrm{pH}$ and soil OM content. 
Table 2. Variability in soil properties and P-sorption capacity $\left(\mathrm{K}_{\mathrm{f}}\right)$ for different soil types in Ethiopian highlands

\begin{tabular}{|c|c|c|c|c|c|c|c|c|c|}
\hline Soil type & $\begin{array}{l}\text { Clay } \\
(\%)\end{array}$ & $\begin{array}{l}\mathrm{pH}- \\
\mathrm{H}_{2} \mathrm{O}\end{array}$ & $\begin{array}{l}\text { OM } \\
(\%)\end{array}$ & $\begin{array}{l}\text { Exch.Al }^{3+} \\
(\mathrm{cmol} \mathrm{kg})\end{array}$ & $\begin{array}{c}\text { Exch. } \mathrm{H}^{+} \\
(\mathrm{cmol} \mathrm{kg})\end{array}$ & $\begin{array}{c}\text { Exch. Ac } \\
\left(\mathrm{cmol} \mathrm{kg}^{-1}\right)\end{array}$ & $\begin{array}{c}\mathrm{Al}_{2} \mathrm{O}_{3} \\
(\%)\end{array}$ & $\begin{array}{c}\mathrm{Fe}_{2} \mathrm{O}_{3} \\
(\%)\end{array}$ & $\begin{array}{c}\mathrm{K}_{\mathrm{f}} \\
\left(\mathrm{mg} \mathrm{kg}^{-1}\right)\end{array}$ \\
\hline Nitisols & $51.7^{a}$ & 5.71 & $3.8^{b}$ & $0.0^{\mathrm{b}}$ & 0.52 & $0.52^{\mathrm{ab}}$ & $26.7^{a}$ & $16 .^{a}$ & $280^{b}$ \\
\hline Luvisols & $48.7^{\mathrm{ab}}$ & 5.73 & $3.83^{b}$ & $0.26^{\mathrm{ab}}$ & 0.35 & $0.61^{\mathrm{ab}}$ & $23.9^{\mathrm{ab}}$ & $15.9^{a}$ & $336^{\mathrm{ab}}$ \\
\hline Alisols & $54.7^{\mathrm{a}}$ & 4.8 & $3.36^{b}$ & $1.18^{\mathrm{a}}$ & 0.49 & $1.67^{a}$ & $22.6^{b}$ & $13.3^{b}$ & $413^{a}$ \\
\hline Andosols & $36^{b}$ & 6.3 & $7.51^{a}$ & $0.13^{b}$ & 0.11 & $0.24^{b}$ & $14.1^{c}$ & $9.24^{c}$ & $299^{b}$ \\
\hline Mean & 47.8 & 5.63 & 4.62 & 0.39 & 0.37 & 0.76 & 21.8 & 13.6 & 332 \\
\hline LSD\% & 15.42 & 1.97 & 1.87 & 1.02 & 0.87 & 1.19 & 3.74 & 1.67 & 0.15 \\
\hline SE & 5.45 & 0.69 & 0.66 & 0.36 & 0.30 & 0.42 & 1.30 & 0.59 & 32.79 \\
\hline F-value & 6.79 & 2.34 & 25.52 & 6.50 & 1.09 & 6.63 & 50.8 & 86.6 & 9.70 \\
\hline P-value & 0.02 & 0.17 & 0.008 & 0.02 & 0.42 & 0.02 & 0.001 & $<0.001$ & 0.01 \\
\hline Sign. & 0.05 & $\mathrm{Ns}$ & 0.001 & 0.05 & $\mathrm{Ns}$ & 0.05 & 0.001 & 0.001 & 0.05 \\
\hline
\end{tabular}

Notes: In the same column, means indicated by different letters are significantly varied at $p<0.05$, ns $=$ non-significant $(P>$ 0.05), $\mathrm{OM}=$ organic matter, Exch $\mathrm{Al}^{3+}=$ Exchangeable aluminum, Exch $\mathrm{H}^{+}=$Exchangeable hydrogen, Exch $\mathrm{Ac}=$ Exchangeable acidity, $\mathrm{Al}_{2} \mathrm{O}_{3}=$ aluminum oxide, $\mathrm{Fe}_{2} \mathrm{O}_{3}=$ iron oxide.

\section{DISCUSSION}

The variation in the $K_{f}$ content of the soils could be attributed to the difference in the soil $\mathrm{pH}$, exch. $\mathrm{Al}^{3+}$, clay, and $\mathrm{OM}$ in the soils and the percentage of $\mathrm{Al}_{2} \mathrm{O}_{3}$ and $\mathrm{Fe}_{2} \mathrm{O}_{3}$ in the soil (Table 2 ). Very high clay content $(54.7 \%)$, strongly acidic soil reaction $(\mathrm{pH} 4.8)$, high level of exch. $\mathrm{Al}^{3+}\left(1.18 \mathrm{mg} \mathrm{kg}^{-1}\right)$ in the soil solution and moderate percentage of OM (3.36\%) content in Alisols resulted in the highest $\mathrm{K}_{\mathrm{f}}\left(413 \mathrm{mg} \mathrm{kg}^{-1}\right)$ and $\mathrm{EPR}_{\mathrm{f}}\left(32.33 \mathrm{mg} \mathrm{kg}^{-1}\right)$ while, moderately acidic soil reaction $(\mathrm{pH}$ 5.7), high $\mathrm{OM}$ content $(3.8 \%)$ and nil exch. $\mathrm{Al}^{3+}$ in Nitisols attributed to the lowest $\mathrm{K}_{\mathrm{f}}\left(280 \mathrm{mg} \mathrm{kg}^{-1}\right)$ and EPRf $\left(25 \mathrm{mg} \mathrm{kg}^{-1}\right)$. Likewise, the $\mathrm{K}_{f}$ and EPR $\mathrm{R}_{\mathrm{f}}$ Luvisols and Andosols were varied based on these soil properties. This finding is similar to the results of (Wang et al., 2017). The $\mathrm{K}_{\mathrm{f}}$ values of the soils of this study were the intermediate values $\left(280-413 \mathrm{mg} \mathrm{P} \mathrm{kg}^{-1}\right)$ detected from (Melese et al., 2015) for the soils of Farta district, in the Northwestern Highlands of Ethiopia which varies from 80 to $259 \mathrm{mg} \mathrm{P} \mathrm{kg}^{-1}$ and those $\mathrm{K}_{\mathrm{f}}$ value stated by Wolde and Haile (2015) in soils from Bule District, in the Southern Ethiopia, which varies from 479 to $487 \mathrm{mg} \mathrm{P} \mathrm{kg}^{-1}$. According to the rating established by Buresh et al. (1997) Nitisols, Luvisols, and Andosols were classified under moderate Phosphorus sorbing (280-316 mg $\mathrm{P} \mathrm{kg}{ }^{-1}$ ) soils. Alisols with $\mathrm{K}_{\mathrm{f}}$ values of $413 \mathrm{mg} \mathrm{P} \mathrm{kg}^{-1}$ ) were grouped under high P sorbing soils (Table 2).

The Soil External Phosphorus Requirement (EPRf), Alisols with the highest PBC ( $\left.471 \mathrm{~L} \mathrm{~kg}^{-1}\right)$ had the highest capacity to restore a unit change in soil solution $\mathrm{P}$ and Keep a productive solution $P$ concentration and make lower the amount of EPR $\mathrm{f}_{\text {. }}$ Because of this, the external phosphorous requirement was not significantly differed among the soil types. The observed $E^{E P R}$ in the soils is more than double of the previously recommended amounts (20 kg $\left.\mathrm{P} \mathrm{ha}{ }^{-1}\right)$ for Alisols and Andosols, and $30 \mathrm{~kg} P$ for Nitisols and Luvisols. The result of this study revealed the need for twice phosphorus fertilizer application compared to the previously used phosphorus fertilizer of $30 \mathrm{~kg} \mathrm{P}^{-1}$ for maize production at Bako and 20 $\mathrm{kg} \mathrm{P} \mathrm{ha}^{-1}$ at Omonada Districts of Oromiya region that supply only15-10 mg P kg-1, which is half of the soils' EPR of 32-25 $\mathrm{mg} \mathrm{P} \mathrm{kg}^{-1}$. According to this finding, 50,60, 64, and $52 \mathrm{~kg} P$ ha${ }^{1}$ for Nitosols, Luvisols, Alisols, and Andosols respectively were recommended for the study areas. Similarly, the Ethio SIS team, Karltun et al. (2013) suggested an initial critical value of $30 \mathrm{mg} \mathrm{P} \mathrm{kg}^{-1}$ soil $\left(60 \mathrm{~kg} \mathrm{P} \mathrm{ha}^{-1}\right)$ for soil fertility mapping and $\mathrm{P}$ fertilizer recommendations in Ethiopia was comparable to the finding of this study.

Correlation between Soil Properties and P-Sorption Capacity, The reason for clay particles positively correlated with soils' sorption capacity $\left(\mathrm{K}_{\mathrm{f}}\right)$ was due to, the fact that finer smaller soil particles (clays) are more reactive and have greater P-retention capacity due to the larger surface area compared to larger soil particles (Jiang et al., 2015). Weihrauch and Opp (2018) also stated that most of the time clay minerals have a more net negative charge than chelating metal cations than sorb Phosphate. The soil $\mathrm{pH}$ was negatively correlated with $\mathrm{K}_{\mathrm{f}}$. As the $\mathrm{pH}$ increased, $\mathrm{K}_{\mathrm{f}}$ decreased due to the increase in electrostatic repulsion created by the increase in negative surface charges.

Table 3. The correlation coefficient between soil properties and P-sorption capacity $\left(\mathrm{K}_{\mathrm{f}}\right)$

\begin{tabular}{|c|c|c|c|}
\hline $\begin{array}{c}\text { Selected Soil } \\
\text { properties }\end{array}$ & $\begin{array}{c}\text { Correlation } \\
\text { coefficient }(r)\end{array}$ & $p$-value & Significance \\
\hline Clay content vs Kf & 0.55 & 0.45 & Ns \\
\hline $\mathrm{Kf}$ vs $\mathrm{pH}-\mathrm{H}_{2} \mathrm{O}$ & -0.82 & 0.18 & Ns \\
\hline Kf vs OM & -0.54 & 0.46 & Ns \\
\hline Kf vs Exch. $\mathrm{Al}^{3+}$ & $0.96 *$ & 0.04 & $*$ \\
\hline Kf vs Exch. $\mathrm{H}^{+}$ & 0.41 & 0.59 & Ns \\
\hline Kf vs Exch. Acidity & 0.73 & 0.27 & Ns \\
\hline $\mathrm{Kf}$ vs $\mathrm{Al}_{2} \mathrm{O}_{3}$ & 0.17 & 0.83 & Ns \\
\hline $\mathrm{Kf}$ vs $\mathrm{Fe}_{2} \mathrm{O}_{3}$ & 0.15 & 0.85 & Ns \\
\hline $1 / \mathrm{n}$ vs Clay & 0.53 & 0.47 & Ns \\
\hline $1 / \mathrm{n}$ vs $\mathrm{pH}$ & -0.88 & 0.12 & Ns \\
\hline $1 / \mathrm{n}$ vs $\mathrm{OM}$ & -0.45 & 0.55 & Ns \\
\hline $1 / \mathrm{n}$ vs $\mathrm{Al}^{3+}$ & $1.00 * * *$ & 0.00001 & $* * *$ \\
\hline $1 / \mathrm{n}$ vs $\mathrm{Kf}$ & $0.95^{*}$ & 0.05 & $*$ \\
\hline
\end{tabular}
Significant at $(P \leq 0.05)$; $n s=$ non-Significant $(P>0.05)$; $\mathrm{OM}=$ Organic matter; Exch $\mathrm{Al} 3+=$ Exchangeable aluminium; Exch $\mathrm{H}+=$ Exchangeable hydrogen; Exch $\mathrm{Ac}$ = Exchangeable acidity; $\mathrm{Al} 2 \mathrm{O} 3$ = aluminium oxide; Fe2O3 = iron oxide; $1 / n=$ sorption energy. 
The $\mathrm{K}_{\mathrm{f}}$ had a negative relation with the soil OM. When the soil $\mathrm{OM}$ increased, the $\mathrm{K}_{\mathrm{f}}$ decreased. Similarly, Wolde and Haile (2015) stated, presence of OM decreased $\mathrm{K}_{\mathrm{f}}$ of the soils due to the organic anions occupying the adsorption sites. Weihrauch and Opp (2018) also noted, organic acids chelate $\mathrm{Fe} / \mathrm{Al} / \mathrm{Ca} / \mathrm{Mg}$ on oxide surfaces and hinder $\mathrm{P}$ sorption. For this particular study, a significantly $(P \leq 0.05)$ positive relation between $\mathrm{K}_{\mathrm{f}}$ and exch. $\mathrm{Al}^{3+}$ revealed, $\mathrm{Al}^{3+}$ was the main contributor for phosphate sorption in high $\mathrm{P}$ fixing soils (Alisols). The current finding is in concord with the findings of Hoseini and Taleshmikaiel (2013) described as insoluble Al phosphates are formed from the reaction of phosphate ions with $\mathrm{Al}^{3+}$. A positive relationship between $\mathrm{K}_{f}$ and exch. $\mathrm{H}^{+}$ indicates phosphate becomes less available at lower soils $\mathrm{pH}$. Also, $\mathrm{K}_{\mathrm{f}}$ had a positive relationship with $\mathrm{Al}_{2} \mathrm{O}_{3}$ and $\mathrm{Fe}_{2} \mathrm{O}_{3}$ as these oxides much contributed toward the increased $\mathrm{K}_{\mathrm{f}}$ of the soils (Table 3 ). In addition, Al and Fe have a very high $\mathrm{K}_{\mathrm{f}}$ in pure systems compared to their oxide forms since the oxides of $\mathrm{Fe}$ and $\mathrm{Al}$ are important cementing agents in soils which reduce the total surface area; therefore absorption sites (Reza, 2014).

\section{CONCLUSION}

There were clear variations in P sorption capacity and, therefore, External Phosphorus Requirement between soils of the study areas. The highest $\mathrm{K}_{\mathrm{f}}\left(413 \mathrm{mg} \mathrm{kg}^{-1}\right)$ was observed for Alisols and the lowest $\mathrm{K}_{\mathrm{f}}\left(280 \mathrm{mg} \mathrm{kg}^{-1}\right)$ was for Nitisols, even though, statistically no significant difference in the external phosphorus requirement. The actual quantity of $P$ required by Nitisols, Luvisols, Alisols, and Andosols were 25, 30,32 , and $26\left(\mathrm{mg} \mathrm{kg}^{-1}\right)$ respectively. The previously blanket $P$ fertilizer recommendation in the country without considering differences among soil types is inadequate for optimal crops production. From the current study, $50 \mathrm{~kg} \mathrm{P} \mathrm{ha}^{-1}, 60 \mathrm{~kg} \mathrm{P} \mathrm{ha}^{-1}$, $56 \mathrm{~kg} P \mathrm{ha}^{-1}$ and $52 \mathrm{~kg} \mathrm{P} \mathrm{ha}^{-1}$ can be recommended for optimum crop production on Nitisols, Luvisols, Alisols, and Andosols respectively.

\section{Declaration of Competing Interest}

The authors declare no competing financial or personal interests that may appear and influence the work reported in this paper.

\section{References}

Afsar, M. Z., Hoque, S., \& Osman, K. (2012). A comparison of the Langmuir, Freundlich and Temkin equations to describe phosphate sorption characteristics of some representative soils of Bangladesh. International Journal of Soil Science, 7(3), 91. https://doi.org/10.3923/ijss.2012.91.99

Beretta, A. N., Silbermann, A. V., Paladino, L., Torres, D., Bassahun, D., Musselli, R., \& García-Lamohte, A. (2014). Soil texture analyses using a hydrometer: modification of the Bouyoucos method. Ciencia $e$ investigación agraria, 41, 263-271. http://www.scielo.cl/scielo.php?script=sci_arttext\&pi d=S0718-16202014000200013\&nrm=iso

Buresh, R. J., Sánchez, P. A., \& Calhoun, F. (1997). Replenishing soil fertility in Africa (Vol. 51). Soil Science
Society

of

America

https://doi.org/10.2136/sssaspecpub51

Dari, B., Nair, V. D., Colee, J., Harris, W. G., \& Mylavarapu, R. (2015). Estimation of phosphorus isotherm parameters: a simple and cost-effective procedure [Original Research]. Frontiers in Environmental Science, https://doi.org/10.3389/fenvs.2015.00070

Elias, E. (2016). Soils of the Ethiopian Highlands: Geomorphology and Properties. CASCAPE Project, ALTERA, Wageningen University and Research Centre (Wageningen UR). The Netherlands.

Elias, E., Okoth, P. F., \& Smaling, E. M. A. (2019). Explaining bread wheat (Triticum aestivum) yield differences by soil properties and fertilizer rates in the highlands of Ethiopia. Geoderma, 339, 126-133. https://doi.org/10.1016/j.geoderma.2018.12.020

Fan, S.-S., Chang, F.-H., Hsueh, H.-T., \& Ko, T.-H. (2016). Measurement of Total Free Iron in Soils by $\mathrm{H}<$ sub $>2</$ sub $>\mathrm{S}$ Chemisorption and Comparison with the Citrate Bicarbonate Dithionite Method. Journal of Analytical Methods in Chemistry, 2016, 7213542. https://doi.org/10.1155/2016/7213542

Getie, A., Kiflu, A., \& Meteke, G. (2021). Phosphorus Sorption Characteristics of Luvisols and Nitisols in North Ethiopian Soils. Applied and Environmental Soil Science, 2021, 8823852. https://doi.org/10.1155/2021/8823852

Gonzalez-Rodriguez, S., \& Fernandez-Marcos, M. L. (2018). Phosphate sorption and desorption by two contrasting volcanic soils of equatorial Africa. PeerJ, 6, e5820. https://doi.org/10.7717/peerj.5820

Hanyabui, E., Apori, S. O., Frimpong, K. A., Atiah, K., Abindaw, T., Ali, M., Asiamah, J. Y., \& Byalebeka, J. (2020). Phosphorus sorption in tropical soils. AIMS Agriculture and Food, 5(4), 599-616. https://doi.org/10.3934/agrfood.2020.4.599

Hoseini, Y., \& Taleshmikaiel, R. D. (2013). Comparison of phosphorus adsorption isotherms in soil and its relation to soil properties. International Journal of Agriculture, 3(1), 163.

Jiang, X., Bol, R., Willbold, S., Vereecken, H., \& Klumpp, E. (2015). Speciation and distribution of $P$ associated with $\mathrm{Fe}$ and $\mathrm{Al}$ oxides in aggregate-sized fraction of an arable soil. Biogeosciences, 12(21), 6443-6452. https://doi.org/10.5194/bg-12-6443-2015

Karltun, E., Mamo, T., Bekele, T., Gameda, S., \& Kidanu, S. (2013). Ethiopian Soil Information System towards improved fertilizer recommendations in Ethiopia. Nutrient indices for categorization of fertilizer blends from EthioSIS District soil inventory data discussion paper.

Kisinyo, P., Othieno, C., Gudu, S., Okalebo, J., Opala, P., Maghanga, J., Ng'etich, W., Agalo, J., Opile, R., \& Kisinyo, J. (2015). Phosphorus sorption and lime requirements of maize growing acid soils of Kenya. https://doi.org/10.5539/sar.v2n2p116

Lestari, Y., Maas, A., Purwanto, B. H., \& Utami, S. N. H. (2016). The influence of lime and nitrogen fertilizer on soil 
acidity, growth and nitrogen uptake of corn in total reclaimed potential acid sulphate soil. Journal of Agricultural Science, 8(12), 197-205. https://doi.org/10.5539/jas.v8n12p197

Maluf, H. J. G. M., Silva, C. A., Curi, N., Norton, L. D., \& Rosa, S. D. (2018). Adsorption and availability of phosphorus in response to humic acid rates in soils limed with CaCO 3 or MgCO 3. Ciência e Agrotecnologia, 42, 7-20. https://doi.org/10.1590/1413-70542018421014518

Melese, A., Gebrekidan, H., Yli-Halla, M., \& Yitaferu, B. (2015). Phosphorus Status, Inorganic Phosphorus Forms, and Other Physicochemical Properties of Acid Soils of Farta District, Northwestern Highlands of Ethiopia. Applied and Environmental Soil Science, 2015, 748390. https://doi.org/10.1155/2015/748390

Muindi, E. M., Mrema, J., Semu, E., Mtakwa, P., \& Gachene, C. (2015). Effects of lime-aluminium-phosphate interactions on maize growth and yields in acid soils of the Kenya highlands. American Journal of Agriculture and Forestry, 3(6), 244-252. https://doi.org/10.11648/j.ajaf.20150306.11

Reza, M. A. (2014). Phosphate Sorption Behavior in Bajoa and Gopalpur Soil Series [Thesis for B.Sc(Hon's), Khulna University]. https://doi.org/10.13140/2.1.2529.1044

SAS Institute Inc. (2019). SAS/SHARE ${ }^{\circledR}$ 9.4: User's Guide, Second Edition. https://documentation.sas.com/doc/en/pgmsascdc/9 .4_3.5/shrref/titlepage.htm

Shirvani, M., Shariatmadari, H., \& Kalbasi, M. (2005). Phosphorus Buffering Capacity Indices as Related to Soil Properties and Plant Uptake. Journal of Plant Nutrition, 28(3), 537-550. https://doi.org/10.1081/PLN-200049235
Tamungang, N. E. B., David, M.-Z. A., Alakeh, M. N., \& Adalbert, O. A. (2014). Phosphorus adsorption isotherms in relation to soil characteristics of some selected volcanic affected soils of Foumbot in the West Region of Cameroon. International Journal of Soil Science, 11(2), 19-28. https://doi.org/10.3923/ijss.2016.19.28

Thuy, P. T. P., Hoa, N. M., \& Dick, W. A. (2020). Reducing Phosphorus Fertilizer Input in High Phosphorus Soils for Sustainable Agriculture in the Mekong Delta, Vietnam. Agriculture, 10(3), 87. https://www.mdpi.com/2077-0472/10/3/87

Towett, E. K., Shepherd, K. D., \& Cadisch, G. (2013). Quantification of total element concentrations in soils using total X-ray fluorescence spectroscopy (TXRF). Science of The Total Environment, 463-464, 374-388. https://doi.org/10.1016/j.scitotenv.2013.05.068

Wang, B., Sun, J. S., Liu, H., \& Ma, Y. B. (2017). The characteristics of phosphorus adsorption and desorption in gray desert soil of Xinjiang, China. IOP Conference Series: Earth and Environmental Science, 77, $012020 . \quad$ https://doi.org/10.1088/17551315/77/1/012020

Weihrauch, C., \& Opp, C. (2018). Ecologically relevant phosphorus pools in soils and their dynamics: The story so far. Geoderma, 325, 183-194. https://doi.org/10.1016/j.geoderma.2018.02.047

Wolde, Z., \& Haile, W. (2015). Phosphorus sorption isotherms and external phosphorus requirements of some soils of southern Ethiopia. African Crop Science Journal, 23(2), 89-99. https://www.ajol.info/index.php/acsj/article/view/11 7723 